\title{
HUBUNGAN BERAT DAN TINGGI BADAN ORANG TUA DENGAN STATUS GIZI BALITA DI KABUPATEN ACEH BESAR
}

\author{
The Relation Weight and Height of Parents with Nutritional Status of Children at Aceh Besar \\ District
}

\author{
Ampera Miko, ${ }^{1}$ Agus Hendra Al-Rahmad ${ }^{2}$ \\ 1Jurusan Gizi Politeknik Kesehatan Kemenkes Aceh, Kampus Terpadu, Jl. Soekarno-Hatta, \\ Lampeunerut Aceh Besar. 23352. \\ 2Jurusan Gizi Politeknik Kesehatan Kemenkes Aceh, Kampus Terpadu, Jl. Soekarno-Hatta, \\ Lampeunerut Aceh Besar. 23352. \\ E-mail: checoks@yahoo.com
}

\begin{abstract}
The nutrition status of population in the district of Aceh was considered as a public health problem. The malnutrition of under five year children such as wasting, stunting and underweight has brought a negative impact on the health of the community. Malnutrition was -among other factors - influenced by family characteristic such as weight and height of the parents. The study was conducted in Aceh Besar. It used cross-sectional design with the sample of 300 households with child aged under five years old. The research used secondary and primary data of PSG Aceh 2015. Data was obtained through documentation study and processed through data editing, coding, transferring and tabulating. The data was analyzed by univariate and bivariate using chi-square test. The result has shown that there were relationship between height and weight of the parents with nutritional status of the children using indicators of WFH and HFA $(p<0,05)$. However, it was not true for the mother's weight $(p>0,05)$. Weight and height of the fathers shown the relationship $(p<0,05)$ with nutritional status (WFA) of the children, but not for the mother's weight and height $(p>0,05)$. In conclusion, the acute and chronic nutritional problems in the district of Aceh Besar were influenced by anthropometric status of the parents, especially the weight and height of the father. It was recommended that improvement of nutritional problems should be done through a direct approach such as growth monitoring, counseling on exclusive breastfeeding, providing of vitamin A and intensified efforts on changing of clean and healthy behavior.
\end{abstract}

Keywords: nutritional status, children, weight and height of parents

\begin{abstract}
ABSTRAK
Kabupaten Aceh mempunyai permasalahan kesehatan berdasarkan situasi status gizi. Balita mengalami malnutirisi seperti wasting, stunting dan underweight yang berdampak terhadap masalah kesehatan. Malnutrisi terjadi akibat keadaan gizi mapun faktor keturunan dari orang tua. Tujuan penelitian untuk mengukur hubungan berat badan dan tinggi badan orang tua dengan status gizi balita. Penelitian berdesain potong-lintang, dilakukan di Aceh Besar dengan sampel rumah tangga yang mempunyai balita sebanyak 300 RT. Penelitian menggunakan data sekunder hasil PSG Aceh 2015, diperoleh melalui studi dokumentasi/observasi dan diolah mulai tahapan editing, coding, transfering sampai tabulating. Analisis data univariat dan bivariat menggunakan uji Chi-Square. Hasil penelitian, terdapat hubungan berat dan tinggi badan orang tua dengan status gizi balita berdasarkan indikator $B B / T B$ dan $T B / U(p<0,05)$, tetapi tidak untuk berat badan ibu. Berat dan tinggi badan kepala keluarga menunjukkan hubungan $(p<0,05)$ dengan status gizi balita (BB/U), tetapi berat dan tinggi badan ibu tidak menunjukkan hubungannya). Kesimpulan, tingginya masalah gizi kronis dan akut di Kabupaten Aceh Besar merupakan akibat berat dan tinggi badan orang tua yang berperan dalam besarnya prevalensi gizi terutama berat dan tinggi badan kepala keluarga. Saran, perbaikan masalah gizi dapat dilakukan melalui pendekatan secara langsung yaitu pemantauan pertumbuhan, penyuluhan tentang ASI eksklusif dan Vitamin A serta MP-ASI serta upaya terhadap perilaku hidup bersih dan sehat (PHBS).
\end{abstract}

Kata kunci: status gizi, balita, berat dan tinggi badan orang tua 


\section{PENDAHULUAN}

D isparitas status kesehatan terjadi menurut tingkatan sosial ekonomi, antarkawasan dan antar-perkotaan-pedesaan. Angka kematian bayi dan balita pada golongan miskin hampir empat kali lebih tinggi dibandingkan terkaya. Tingginya angka kematian bayi dan angka kematian ibu melahirkan serta prevalensi gizi kurang dan buruk di daerah perdesaan lebih tinggi mengakibatkan situasi kesehatan di Indonesia menjadi pekerjaan rumah yang belum terselesaikan. ${ }^{1}$ Penekanan hal tersebut dituangkan dalam agenda pembangunan pasca-2015 yang secara spesifik termuat dalam RPJMN 2015-2019, beberapa sasaran pokok, yakni menurunnya prevalensi underweight (gizi buruk dan kurang) menjadi 17,0 persen dan prevalensi stunting (sangat pendek dan pendek) pada anak di bawah 2 tahun menjadi 28,0 persen. Selain itu prevalensi wasting (sangat kurus dan kurus) menjadi 9,5\% serta prevalensi bayi dengan berat badan lahir rendah (BBLR) menurun dari 10,2 persen menjadi 8,0 persen. ${ }^{2}$

Sejak tahun 2007 sampai dengan tahun 2013, di Indonesia terdapat enam provinsi yang tidak pernah absen dengan prevalensi gizi kurang serta gizi pendek, yaitu (1) Nusa Tenggara Timur, (2) Papua Barat, (3) Maluku, (4) Aceh, (5) Gorontalo, dan (6) Nusa Tenggara Barat. Permasalahan yang menyebabkan tingginya prevalensi gizi kurang pada beberapa daerah, belum ditemukan langkah intervensi terhadap pemecahan masalah tersebut. ${ }^{3}$ Provinsi Aceh, tahun 2013 prevalensi masalah gizi semakin meningkat dibandingkan tahun 2010, baik terkait angka prevalensi gizi buruk dan kurang $(26,3 \%)$ maupun prevalensi kependekan $(41,5 \%)$, tetapi terjadi penurunan untuk prevalensi kekurusan (15,7\%). ${ }^{4}$ Kabupaten Aceh Besar merupakan salah satu kabupaten dengan permasalah gizi tidak begitu berat. Prevalensi balita gizi buruk dan kurang $(22,1 \%)$ dan balita kekurusan $(5,3 \%)$, sedangkan kependekan masih cukup tinggi sebesar 36,5\%. ${ }^{4}$ Prevalensi tersebut meningkat pada tahun 2015 , yakni balita gizi buruk dan kurang $(26,6 \%)$, balita kekurusan $(22,3 \%)$ hanya prevalensi kependekan dapat diturunkan menjadi 25,0 persen. ${ }^{5}$

Masalah gizi dipengaruhi banyak faktor dan saling mempengaruhi. Salah satunya adalah faktor genetik dari orang tua, yaitu faktor tinggi dan berat badan orang tua. Selain itu, faktor pendidikan, ketersediaan pangan di tingkat rumah tangga, pola asuh konsumsi makanan, pola makan, kepercayaan, tradisi/budaya, dan lain sebagainya. ${ }^{6}$ Beberapa hasil penelitian lain yang menyatakan bahwa status gizi disebabkan oleh karakteristik orang tua seperti ukuran antropometri ibu dan bapak, ${ }^{7}$ seperti tinggi badan orang tua memungkinkan anak memiliki risiko gagal pertumbuhan serta mengalami

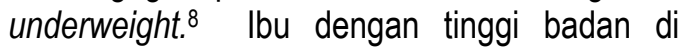
bawah $150 \mathrm{~cm} 74,5$ persen mempunyai anak yang pendek, ${ }^{9}$ ibu dengan tinggi badan $<150$ $\mathrm{cm}$ sebesar 3,4 kali mempunyai anak pendek dan tinggi badan ayah $<162 \mathrm{~cm}$ peluang untuk mempunyai anak pendek sebesar 3,2 kali. ${ }^{7}$

Gaya hidup yang tidak teratur dapat meningkatkan atau menurunkan berat badan, sehingga memungkinkan risiko berbagai penyakit salah satunya, yaitu overweight. ${ }^{10}$ Kelebihan berat badan (prevalensi overweight) semakin tinggi dan terus meningkat di Indonesia sebagai negara berkembang, pada orang dewasa kelebihan berat badan pada usia 25-65 tahun mencapai 26,1 persen. ${ }^{11}$ Kelebihan berat badan orang tua merupakan faktor resiko yang berhubungan dengan status gizi anak,12 menurut Lee et al., orang tua yang cenderung mempunyai kelebihan berat badan sebanyak 39 anak juga mengalami kelebihan berat badan. ${ }^{13}$

Akar permasalahan gizi adalah krisis ekonomi, politik dan sosial dalam masyarakat, sehingga menyebabkan kekurangan pangan, kemiskinan dan tingginya angka inflasi dan pengangguran. Sementara masalah di masyarakat adalah kurangnya pemberdayaan wanita dan sumber daya manusia, rendahnya tingkat pendidikan, pengetahuan dan keterampilan. ${ }^{14}$ Framework penyebab masalah gizi pada balita secara langsung dipengaruhi oleh faktor asupan pangan dan kesehatan. Secara tidak langsung terdapat banyak faktor seperti pola asuh meliputi karakteristik keluarga, aksebilitas pangan, pelayanan kesehatan dan kesehatan dasar. ${ }^{15}$

Situasi gizi balita di Kabupaten Aceh Besar mempunyai permasalah gizi berat menurut indikator $\mathrm{BB} / \mathrm{TB}$ maupun $\mathrm{BB} / \mathrm{U}$ jika dilihat dari hasil PSG 2015. Mengingat status gizi merupakan gambaran terhadap ketiga indicator, yakni berat badan menurut umur $(\mathrm{BB} / \mathrm{U})$, tinggi badan menurut umur (TB/U) dan berat badan 
menurut tinggi badan (BB/TB) terjadi akibat faktor langsung dan tidak langsung, maka berdasarkan hasil riset tersebut menggunakan data sekunder (Data Survei PSG Aceh 2015) perlu dilakukan suatu analisis untuk mengukur faktor tidak langsung, yaitu hubungan berat badan dan tinggi badan orang tua dengan status gizi balita di Kabupaten Aceh Besar. Penelitian ini dapat memberikan gambaran mengenai situasi gizi balita berdasarkan berat dan tinggi badan orang tua.

\section{METODE PENELITIAN}

Penelitian menggunakan studi potonglintang yang dilakukan secara deskriptif analitik. Metode yang ada pada saat penelitian dilakukan atau masalah yang bersifat aktual, sebagaimana dengan keadaan sebenarnya, yakni menjelaskan keadaan dari objek penelitian berdasarkan fakta-fakta sebagaimana adanya dan mencoba menganalisis untuk memberikan kebenaran berdasarkan data yang diperoleh yang terkait status gizi balita. Penelitian dilaksanakan di Kabupaten Aceh Besar, dengan waktu pelaksanaannya, yaitu Maret - September tahun 2016. Pemilihan lokasi berdasarkan hasil survei pemantauan status gizi (PSG) tahun 2015, pada 13 kecamatan. Karakteristik antropometri orang tua mempunyai rata-rata berat badan, yakni $58,8 \mathrm{~kg}$ dengan tinggi badannya $153,1 \mathrm{~cm}$.

\section{Populasi dan sampel analisis}

Populasi merupakan semua rumah tangga yang mempunyai balita usia 6-59 bulan 29 hari yang lahir normal di Kabupaten Aceh Besar. Sampel adalah unit rumah tangga yang terpilih dari populasi. Metode sampling dilakukan secara probability sampling dengan teknik cluster sampling, dengan tahapan, yaitu: (1) tahap pertama memilih klaster kabupaten; dan (2) tahap kedua memilih sampel Rumah Tangga (RT) di setiap klaster. Pada klaster kabupaten akan dipilih 30 klaster, yakni 30 desa/kelurahan, setiap desa diambil sebanyak 10 rumah tangga (RT). Pemilihan klaster di kabupaten dilakukan dengan acak sistematik berdasarkan probability proportional to size (PPS) dengan bantuan tabel random. Sampel dalam penelitian ini, yaitu rumah tangga yang mempunyai balita, yakni sebanyak $300 \mathrm{RT} .{ }^{5}$

\section{Pengolahan dan analisis data}

Penelitian menggunakan data sekunder melalui studi pustaka/laporan riset Survei Pemantauan Status Gizi (PSG) tahun 2015 yang diperoleh pada Dinas Kesehatan Kabupaten Aceh Besar. Adapun data yang akan dikumpulkan, yaitu identitas lokasi, identitas rumah tangga dan responden melalui wawancara, data antropometri orang tua, yakni mengukur tinggi badan dengan kategori normal jika $>160 \mathrm{~cm}$ untuk KK dan $>150 \mathrm{~cm}$ untuk ibu, serta penimbangan berat badan KK dan ibu untuk menilai berat badan ideal menggunakan rumus Broca, ${ }^{17}$ dengan kategori ideal jika \pm 10 persen dari BBI. Data tinggi badan dan berat badan orang tua terdapat beberapa yang missing value sehingga memperlakukan melalui transformasi data menggunakan metode series mean, artinya setiap data tinggi badan dan berat badan yang mempunyai missing value digantikan dengan nilai rata-rata ${ }^{16}$. Data hasil pengukuran antropometri balita yang meliputi tanggal lahir, berat badan melalui penimbangan dengan dacin dengan ketelitian $0,1 \mathrm{~kg}$, data panjang dan tinggi badan melalui pengukur tinggi badan (microtoice) dengan ketelitian 0,1 $\mathrm{cm}$, serta data status gizi meliputi indikator BB/U (gizi buruk, gizi kurang, gizi baik, gizi lebih); TB/U (sangat pendek, pendek dan normal) dan BB/TB (sangat kurus, kurus, normal dan gemuk). Setelah data dikumpulkan, maka selanjutnya dilakukan proses pengolahan data komputerisasi dengan beberapa tahapan, yaitu editing, coding, entry, cleaning data entry. Analisis data dimulai dengan melakukan analisis secara deskriptif. Selanjutnya analisis secara bivariat, yakni untuk mengukur ada tidaknya hubungan antara variabel independent dengan dependent, maka digunakan uji ChiSquare yang bertujuan membuktikan hipotesis yang diajukan dengan $p<0,05$.

\section{HASIL}

Kabupaten Aceh Besar mempunyai luas wilayah sebesar 2.903,50 km2 dengan sebagian besar wilayahnya berada didaratan dan hanya sebagian kecil berada di kepulauan. Sekitar 10 persen desanya merupakan daerah pesisir. Kabupaten Aceh Besar terdiri dari 23 Kecamatan, 68 Mukim, dan 604 Gampong/Desa. Berdasarkan data BPS Aceh Besar, jumlah penduduk pada tahun 2015 
adalah sebanyak 384.618 jiwa, terdiri dari lakilaki berjumlah 197.006 jiwa dan perempuan berjumlah 187.612 jiwa dengan sex ratio, yaitu 105,01. Selanjutnya terdapat 89.054 rumah tangga dengan rata-rata jumlah anggota rumah tangga, yakni 4 jiwa. Situasi derajat kesehatan Kabupaten Aceh Besar dapat dilihat dari berbagai upaya kesehatan yang secara menyeluruh dan berkesinambungan menjadi pilar utama membangun daerah. Indikator penting dan bersifat sensitif untuk mengukur derajat kesehatan masyarakat seperti Angka Kematian Ibu (AKI), Angka Kematian Bayi (AKB), Umur Harapan Hidup (UHH), dan Status Gizi. Angka kematian ibu (AKI) pada tahun 2015 meningkat dibandingkan tahun 2014, yaitu sebanyak 88 orang per $100.000 \mathrm{KH}$, sedangkan AKB cenderung menurun dari tahun 2014 ke tahun 2015, yakni sebanyak 82 orang per 1.000 kelahiran hidup. Selanjutnya situasi status gizi balita di Kabupaten Aceh Besar tahun 2015, jika berdasarkan BBLR terdapat 24 bayi, dengan jumlah balita dibawah garis merah (BGM) terdapat 538 balita. Persentase gizi buruk menurut indeks BB/U mengalami penurunan, yaitu 21 balita dibandingkan tahun 2014, yakni sebanyak 59 balita. $^{18}$

Sampel dalam penelitian ini merupakan semua rumah tangga yang mempunyai balita usia 0-59 bulan 29 hari yang ada di Kabupaten Aceh Besar yang terpilih menggunakan sistem klaster, yaitu sebanyak 300 balita. Berdasarkan dari 13 Kecamatan yang terpilih untuk sampel penelitian hampir tidak menunjukkan perbedaan karakteristik sampel, baik berdasarkan usia maupun jenis kelamin. Berdasarkan usia balita ternyata dari 281 balita diketahui sebanyak 118 balita berusia 6-24 bulan dan 163 balita berusia 25-59 bulan, sedangkan berdasarkan jenis kelamin ternyata yang berjenis kelamin laki-laki sebanyak 143 balita dan berjenis kelamin perempuan sebanyak 138 balita yang terdapat di wilayah Kabupaten Aceh Besar.

Status gizi balita berdasarkan ketiga indikator disajikan menurut kecamatan di Kabupaten Aceh Besar (Gambar 1), terlihat situasi gizi balita dengan indikator BB/TB ternyata Kabupaten Aceh Besar menurut hasil PSG tahun 2015 mempunyai prevalensi kekurusan pada balita sebesar 22,3 persen serta hanya sedikit balita yang mengalami kegemukan $(3,7 \%)$ menurut indikator BB/TB. Berdasarkan kecamatan, prevalensi kekurusan pada balita paling besar terdapat di Kecamatan Darul Imarah $(45,0 \%)$ dan terendah di Kecamatan Lhoknga $(5,0 \%)$, selain itu juga terdapat anak-anak yang mengalami kegemukan paling tinggi, yakni di Kecamatan Kuta Cot Glie (20,0\%). Menurut WHO'19, masalah kesehatan masyarakat sudah dianggap serius bila prevalensi wasting (sangat kurus + kurus) antara 10,0-14,9 persen, dan dianggap kritis bila $\geq 15,0$ persen (BB/TB). Selain itu, status gizi balita dengan indikator TB/U (Gambar 2) menunjukan bahwa Kabupaten Aceh Besar mempunyai prevalensi kependekan pada balita sebesar 25,0 persen. Adapun kecamatan yang paling tinggi prevalensinya, yaitu Kecamatan Kuta Cot Glie $(80,0 \%)$ dan yang paling rendah prevalensinya, yakni Kecamatan Simpang Tiga (5,0\%). Masalah kesehatan masyarakat dianggap berat bila prevalensinya sebesar $30,0-39,9$ persen dan sangat berat bila prevalensi $\geq 40$. Kabupaten Aceh Besar mempunyai masalah derajat kesehatan dengan katagori berat $(25,0 \%)$, dan dua kecamatan yang mempunyai masalah kesehatan yang sangat serius, yaitu Kecamatan Kuta Cot Glie dan Ingin Jaya. Sementara tiga kecamatan lainnya mempunyai masalah yang berat, yakni Kecamatan Indrapuri, Kuta Malaka dan Blang Bintang. Terdapat empat kecamatan yang tidak mempunyai masalah gizi masyarakat ditinjau dari prevalensi kependekan pada balita, menurut batasan WHO (TB/U $<20,0 \%) .{ }^{19}$

Selanjutnya, status gizi balita indikator BB/U memberikan indikasi masalah gizi secara umum, dapat disebabkan masalah gizi kronis atau masalah gizi akut (Gambar 3). Kabupaten Aceh Besar tahun 2015 mempunyai prevalensi balita yang mengalami kekurangan berat badan atau underweight (status gizi buruk + kurang) sebesar 26,7 persen dan kelebihan berat badan (status gizi lebih) hanya sebesar 0,7 persen. Kecamatan Kuta Cot Glie (60,0\%) mempunyai prevalensi balita gizi buruk-kurang tertinggi, dan paling rendah di Kecamatan Lhoknga (10,0\%). Batasan WHO menyebutkan bahwa suatu daerah mempunyai masalah kesehatan masyarakat sudah dianggap serius bila prevalensi gizi buruk-kurang antara 20,0 - 29,9 persen dan dianggap prevalensi sangat tinggi bila $\geq 30$ persen. ${ }^{19}$ Berdasarkan batasan masalah tersebut, dapat disimpulkan bahwa kondisi kesehatan masyarakat di Kabupaten 
Aceh Besar pada tahun 2015 mempunyai masalah yang serius $(26,7 \%)$, selain itu terdapat tujuh kecamatan dengan permasalahan kesehatan yang sangat tinggi, yakni Kecamatan
Kuta Cot Glie, Ingin Jaya, Darul Imarah, Blang Bintang, Mesjid Raya, Baitussalam dan Kuta Malaka.

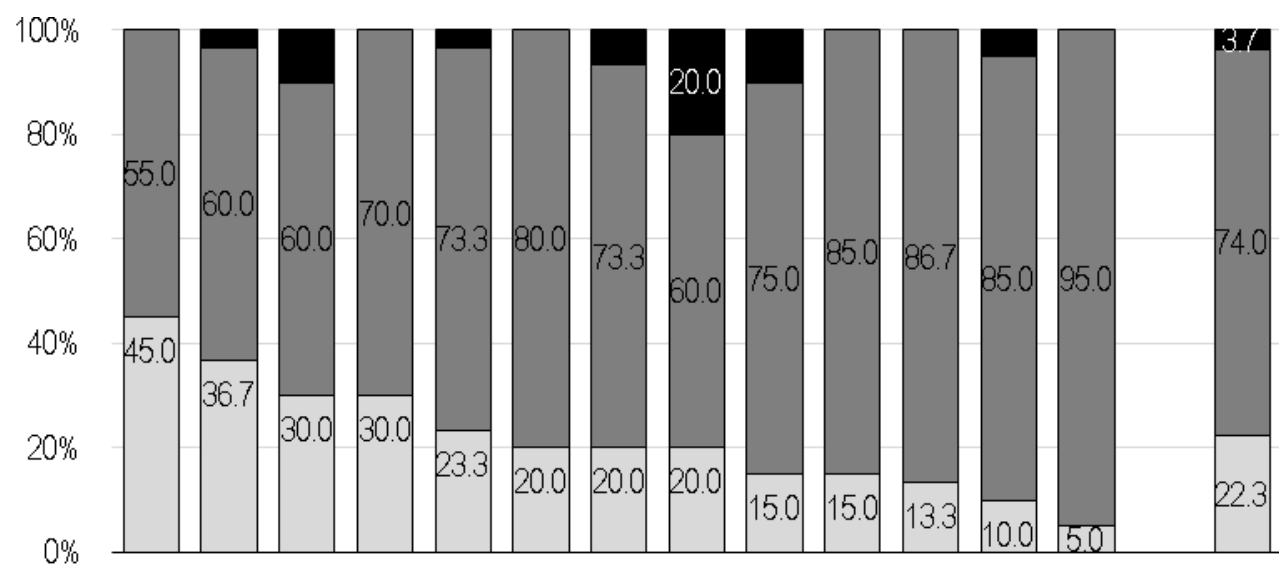

Darul Imarah Baitussalam Kuta Malaka Ingin Jaya Darul Kamal SukaMakmur Lhoknga ACEH BESAR

$\square$ Wasting $\square$ Normal Kegemukan

Gambar 1. Persentase Balita Usia 0 - 59 Bulan menurut Status Gizi dengan Indeks BB/TB Berdasarkan Kecamatan di Kabupaten Aceh Besar

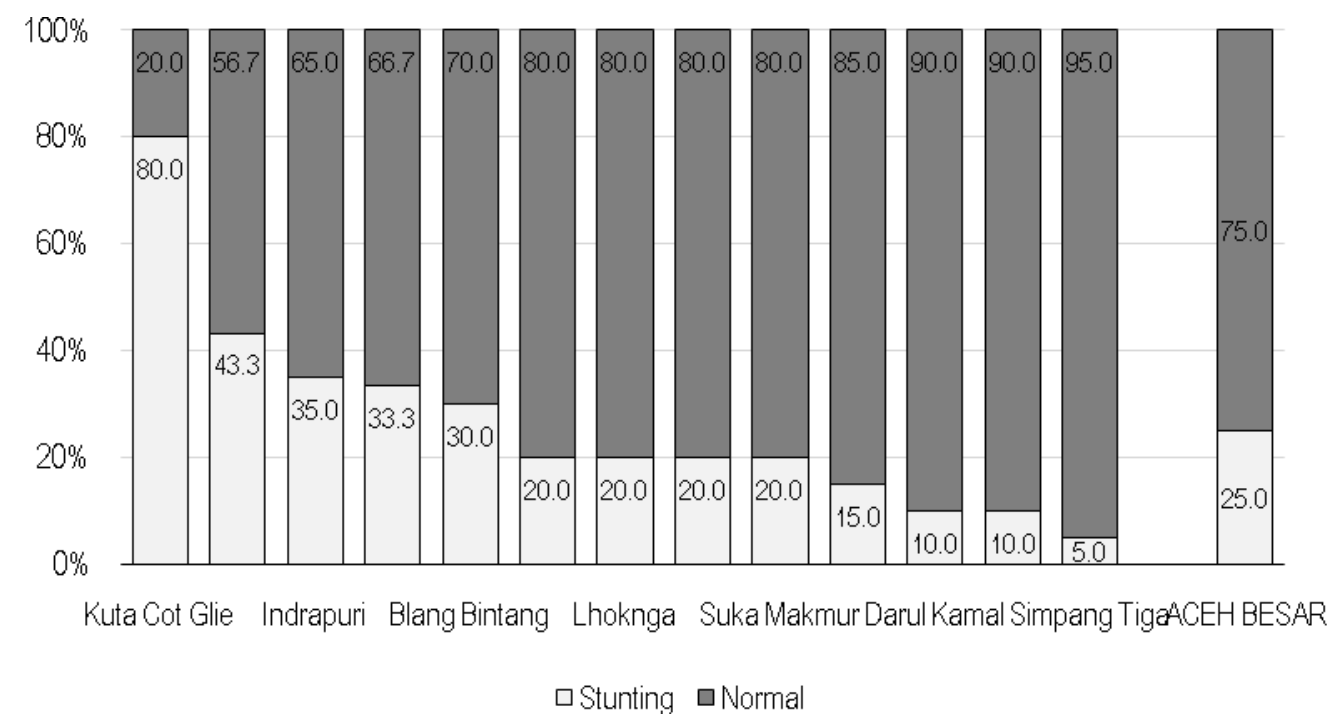

Gambar 2. Persentase Balita Usia 0 - 59 Bulan menurut Status Gizi dengan Indeks TB/U Berdasarkan Kecamatan di Kabupaten Aceh Besar 


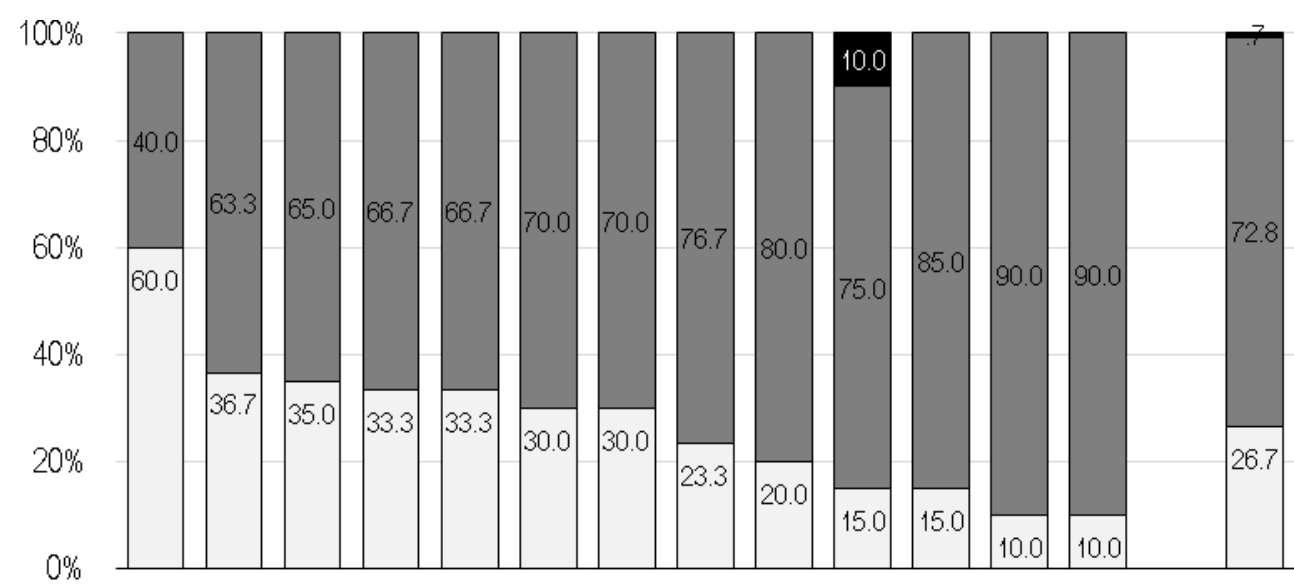

Kuta Cot Glie Darul Imarah Mesjid Raya Kuta Malaka Peukan BadaSimpang Tiga Lhoknga ACEH BESAR

$$
\text { 口Underweight } \square \text { Baik } \mathbf{a} \text { Lebih }
$$

Gambar 3. Persentase Balita Usia 0 - 59 Bulan menurut Status Gizi dengan Indeks BB/U Berdasarkan Kecamatan di Kabupaten Aceh Besar

Tabel 1. Hubungan Berat Badan dan Tinggi Badan Orang Tua dengan Status Gizi Balita (BB/TB) di Kabupaten Aceh Besar

\begin{tabular}{|c|c|c|c|c|c|}
\hline \multirow[b]{2}{*}{ Antropometri } & \multicolumn{3}{|c|}{ Status Gizi Balita (BB/TB) } & \multirow[b]{2}{*}{$\begin{array}{c}\text { Jumlah } \\
\mathrm{n}(\%)\end{array}$} & \multirow[b]{2}{*}{$p$-value } \\
\hline & $\begin{array}{c}\text { Wasting } \\
\mathrm{n}(\%)\end{array}$ & $\begin{array}{c}\text { Normal } \\
\mathrm{n}(\%)\end{array}$ & $\begin{array}{c}\text { Gemuk } \\
\mathrm{n}(\%)\end{array}$ & & \\
\hline $\begin{array}{l}\text { Tinggi badan KK } \\
\text { - } \quad \text { Pendek } \\
\text { - Normal }\end{array}$ & $\begin{array}{l}19(35,8) \\
48(19,4)\end{array}$ & $\begin{array}{r}32(60,4) \\
190(76,9)\end{array}$ & $\begin{array}{l}2(3,8) \\
9(3,6)\end{array}$ & $\begin{array}{r}53(100,0) \\
247(100,0)\end{array}$ & 0,032 \\
\hline $\begin{array}{l}\text { Tinggi badan lbu } \\
\text { - Pendek } \\
\text { - Normal }\end{array}$ & $\begin{array}{l}26(27,7) \\
41(19,9)\end{array}$ & $\begin{array}{r}61(64,9) \\
161(78,2)\end{array}$ & $\begin{array}{l}7(7,4) \\
4(1,9)\end{array}$ & $\begin{array}{r}94(100,0) \\
206(100,0)\end{array}$ & 0,014 \\
\hline $\begin{array}{l}\text { Berat Badan KK } \\
-\quad \text { Tidak ideal } \\
-\quad \text { Ideal }\end{array}$ & $\begin{array}{l}39(31,2) \\
28(16,0)\end{array}$ & $\begin{array}{r}83(66,4) \\
139(79,4)\end{array}$ & $\begin{array}{l}3(2,4) \\
8(4,6)\end{array}$ & $\begin{array}{l}125(100,0) \\
175(100,0)\end{array}$ & 0,006 \\
\hline $\begin{array}{ll}\text { Berat Badan Ibu } & \text { Tidak ideal } \\
- & \text { Ideal } \\
\end{array}$ & $\begin{array}{l}52(21,1) \\
15(28,3) \\
\end{array}$ & $\begin{array}{r}184(74,5) \\
38(71,7) \\
\end{array}$ & $\begin{array}{r}11(4,5) \\
0(0,0) \\
\end{array}$ & $\begin{array}{r}247(100,0) \\
53(100,0) \\
\end{array}$ & 0,186 \\
\hline Jumlah & $67(22,3)$ & $222(74,0)$ & $11(3,7)$ & $300(100,0)$ & \\
\hline
\end{tabular}

Hasil uji statistik Chi-Square yang digunakan untuk melihat hubungan tinggi badan dan berat badan dengan status gizi balita di Kabupaten Aceh Besar disajikan pada Tabel 1 (indeks BB/TB), Tabel 2 (indeks TB/U) dan Tabel 3 (indeks $\mathrm{BB} / \mathrm{U}$ ). Hasil analisis data (Tabel 1) menunjukkan bahwa berdasarkan tinggi badan orang tua diperoleh nilai probabilitas untuk tinggi badan KK $(p=0,032)$ dan tinggi badan ibu $(p=0,014)$, sehingga dapat disimpulkan terdapat hubungan ukuran tinggi badan orang tua dengan status gizi balita menurut indeks $\mathrm{BB} / \mathrm{TB}(\mathrm{p}$-value $<0,05)$. Begitu juga dengan berat badan $\mathrm{KK}$, diperoleh hasil statistik, yaitu $p=0,006$, sedangkan berat badan ibu mempunyai nilai $p=0,186$. Hasil statistik tersebut dapat disimpulkan, bahwa terdapat hubungan signifikan antara berat badan KK dengan status gizi balita menurut indeks BB/TB ( $p$-value < 0,05), tetapi berat badan ibu tidak menunjukkan hubungannya dengan status gizi balita $(p$-value $>0,05) d i$ Kabupaten Aceh Besar. 
Tabel 2. Hubungan Berat Badan dan Tinggi Badan Orang Tua dengan Status Gizi Balita (TB/U) di Kabupaten Aceh Besar

\begin{tabular}{|c|c|c|c|c|}
\hline \multirow[b]{2}{*}{ Antropometri } & \multicolumn{2}{|c|}{ Status Gizi Balita (TB/U) } & \multirow[b]{2}{*}{$\begin{array}{c}\text { Jumlah } \\
\mathrm{n}(\%)\end{array}$} & \multirow[t]{2}{*}{$p$-value } \\
\hline & $\begin{array}{l}\text { Stunting } \\
\mathrm{n}(\%)\end{array}$ & $\begin{array}{c}\text { Normal } \\
\mathrm{n}(\%)\end{array}$ & & \\
\hline $\begin{array}{l}\text { Tinggi badan KK } \\
\text { - Pendek } \\
\text { - } \quad \text { Normal }\end{array}$ & $\begin{array}{l}21(39,6) \\
54(21,9)\end{array}$ & $\begin{array}{r}32(60,4) \\
193(78,1)\end{array}$ & $\begin{array}{r}53(100,0) \\
247(100,0)\end{array}$ & 0,011 \\
\hline $\begin{array}{l}\text { Tinggi badan Ibu } \\
-\quad \text { Pendek } \\
-\quad \text { Normal } \\
\text { Berat Badan KK }\end{array}$ & $\begin{array}{l}32(34,0) \\
43(20,9)\end{array}$ & $\begin{array}{r}62(66,0) \\
163(79,1)\end{array}$ & $\begin{array}{r}94(100,0) \\
206(100,0)\end{array}$ & 0,021 \\
\hline $\begin{array}{ll}\text { - } & \text { Tidak ideal } \\
\text { - } & \text { Ideal }\end{array}$ & $\begin{array}{l}40(32,0) \\
35(20,0)\end{array}$ & $\begin{array}{r}85(68,0) \\
140(80,0)\end{array}$ & $\begin{array}{l}125(100,0) \\
175(100,0)\end{array}$ & 0,026 \\
\hline $\begin{array}{l}\text { Berat Badan Ibu } \\
-\quad \text { Tidak ideal } \\
-\quad \text { Ideal }\end{array}$ & $\begin{array}{l}61(24,7) \\
14(26,4)\end{array}$ & $\begin{array}{r}186(75,3) \\
39(73,6) \\
\end{array}$ & $\begin{array}{r}247(100,0) \\
53(100,0) \\
\end{array}$ & 0,930 \\
\hline Jumlah & $75(25,0)$ & $225(75,0)$ & $300(100,0)$ & \\
\hline
\end{tabular}

Tabel 3. Hubungan Berat Badan dan Tinggi Badan Orang Tua dengan Status Gizi Balita (BB/U) di Kabupaten Aceh Besar

\begin{tabular}{|c|c|c|c|c|c|}
\hline \multirow[b]{2}{*}{ Antropometri } & \multicolumn{3}{|c|}{ Status Gizi Balita (BB/U) } & \multirow[b]{2}{*}{$\begin{array}{c}\text { Jumlah } \\
\mathrm{n}(\%)\end{array}$} & \multirow[b]{2}{*}{$p$-value } \\
\hline & $\begin{array}{c}\text { Underweight } \\
\mathrm{n}(\%)\end{array}$ & $\begin{array}{c}\text { Baik } \\
\mathrm{n}(\%)\end{array}$ & $\begin{array}{l}\text { Lebih } \\
\mathrm{n}(\%)\end{array}$ & & \\
\hline $\begin{array}{ll}\text { Tinggi badan KK } \\
\text { - } & \text { Pendek } \\
\text { - } & \text { Normal }\end{array}$ & $\begin{array}{l}22(41,5) \\
58(23,5)\end{array}$ & $\begin{array}{r}31(58,5) \\
187(75,7)\end{array}$ & $\begin{array}{l}0(0,0) \\
2(0,8)\end{array}$ & $\begin{array}{r}53(100,0) \\
247(100,0)\end{array}$ & 0,023 \\
\hline $\begin{array}{l}\text { Tinggi badan Ibu } \\
\text { - } \quad \text { Pendek } \\
\text { - }\end{array}$ & $\begin{array}{l}27(28,7) \\
53(25,7)\end{array}$ & $\begin{array}{r}65(69,1) \\
153(74,3)\end{array}$ & $\begin{array}{l}2(2,1) \\
0(0,0)\end{array}$ & $\begin{array}{r}94(100,0) \\
206(100,0)\end{array}$ & 0,089 \\
\hline $\begin{array}{l}\text { Berat Badan KK } \\
-\quad \text { Tidak ideal } \\
-\quad \text { Ideal }\end{array}$ & $\begin{array}{l}50(40,0) \\
30(17,2)\end{array}$ & $\begin{array}{r}75(60,0) \\
143(81,7)\end{array}$ & $\begin{array}{l}0(0,0) \\
2(1,1)\end{array}$ & $\begin{array}{l}125(100,0) \\
175(100,0)\end{array}$ & 0,000 \\
\hline $\begin{array}{l}\text { Berat Badan Ibu } \\
-\quad \text { Tidak ideal } \\
-\quad \text { Ideal } \\
\end{array}$ & $\begin{array}{l}60(24,3) \\
20(37,7) \\
\end{array}$ & $\begin{array}{r}185(74,9) \\
33(62,3) \\
\end{array}$ & $\begin{array}{l}2(0,8) \\
0(0,0)\end{array}$ & $\begin{array}{l}103(100,0) \\
132(100,0)\end{array}$ & 0,114 \\
\hline Jumlah & $80(26,6)$ & $218(72,7)$ & $2(0,7)$ & $300(100,0)$ & \\
\hline
\end{tabular}

Hubungan tinggi dan berat badan orang tua dengan status gizi balita menurut indikator TB/U (Tabel 2) diperoleh nilai probabilitas untuk tinggi badan KK $(p=0,011)$ dan tinggi badan ibu $(p=$ $0,021)$. Sehingga dapat disimpulkan bahwa terdapat hubungan secara signifikan ( $\mathrm{p}$-value < 0,05 ) antara tinggi badan orang tua dengan status gizi balita (indeks TB/U). Selanjutnya berdasarkan berat badan orang tua, diperoleh nilai probabilitas untuk berat badan KK, yakni $p$
$=0,026$ dan berat badan ibu, yaitu $p=0,930$, berdasarkan hasil tersebut disimpulkan bahwa terdapat hubungan bermakna ( $p$-value $<0,05$ ) antara berat badan KK dengan status gizi balita (indeks TB/U), tetapi berat badan ibu tidak menunjukkan hubungan dengan status gizi balita menurut indeks TB/U ( $p$-value $>0,05)$ di Kabupaten Aceh Besar.

Mengukur hubungan antara antropometri orang tua dengan status gizi balita (indikator 
BB/U) disajikan pada Tabel 3. Menurut tinggi badan orang tua, bahwa hasil uji statistik diperoleh nilai probabilitas terhadap hubungan tinggi badan KK dengan status gizi balita, yakni $p=0,023$, tetapi menurut tinggi badan ibu nilai probabilitasnya, yaitu $p=0,089$, jadi secara proporsional terdapat hubungan signifikan antara tinggi badan KK dengan status gizi balita menurut indeks BB/U (p-value < 0,05), sedangkan berdasarkan tinggi badan ibu tidak menunjukkan hubungan dengan status gizi pada balita ( $p$-value $>0,05$ ) di Kabupaten Aceh Besar. Selanjutnya, berdasarkan hubungan berat badan orang tua dengan status gizi balita diperoleh nilai probabilitas berat badan $\mathrm{KK}(\mathrm{p}=$ $0,000)$ dan berat badan ibu ( $p=0,114)$. Keputusan hasil statistik tersebut, yakni berat badan KK berhubungan signifikan dengan status gizi balita ( $p$-value $<0,05)$, tetapi sebaliknya berat badan ibu tidak menunjukkan hubungan bermakna dengan status gizi balita ( $p$-value > 0,05) di Kabupaten Aceh Besar berdasarkan kondisi data pemantauan status gizi tahun 2015.

\section{BAHASAN}

Kondisi tinggi badan dan berat badan ayah menunjukkan hubungan signifikan dengan staus gizi balita menggunakan indikator BB/TB, begitu juga dengan tinggi badan ibu. Sebaliknya, berdasarkan berat badan ibu tidak menunjukkan hubungan dengan status gizi balita di Kabupaten Aceh Besar. Wasting merupakan indikasi masalah gizi pada balita yang mengalami kurus dan sangat kurus yang sifatnya akut sebagai akibat dari peristiwa yang terjadi dalam waktu singkat, seperti kejadian wabah penyakit, kelaparan dan hal ini berdampak terhadap balita, dan keberlanjutannya akan berakibat pada risiko terkait berbagai penyakit degeneratif pada masa dewasa. ${ }^{4}$ Hasil penelitian di atas yang menyatakan terdapat hubungan berat dan tinggi badan orang tua dengan status gizi balita (BB/TB) sesuai dengan penelitian Yang et al. ${ }^{7}$ bahwa tinggi orang tua baik ibu maupun ayah merupakan faktor yang paling penting mempengaruhi status gizi pada anak umumnya hal ini terjadi pada ibu dengan tinggi badan $<155 \mathrm{~cm}$ mempunyai kecenderungan anak lahir mengalami BBLR dan hal tersebut akan berdampak terhadap malnutrisi, hal tersebut juga didukung oleh Zottarelli et al. ${ }^{8}$ kondisi ibu dengan tinggi badan $<150 \mathrm{~cm}$ memiliki anak dengan risiko gagal pertumbuhan dan perkembangan ke arah yang lebih baik. Berat lahir merupakan prediktor kuat terhadap penentuan ukuran tubuh di kemudian hari. Hal ini karena pada umumnya bayi yang mengalami Intra Uterine Growth Retardation (IUGR) tidak dapat mengejar pertumbuhan ke bentuk normal selama masa kanak-kanak sehingga kecenderungan anak mengalami kekurusan relatif tinggi. ${ }^{20}$ Selain itu terdapat faktor pendukung terhadap tingginya masalah kekurusan di Aceh Besar, yaitu faktor pendidikan dan pekerjaan orang tua. Rendahnya pendidikan orang tua hampir 26,3 31,1 persen mempunyai anak yang kurus dan sangat kurus, hal ini jika akan berlangsung lama sehingga dapat berakibat lebih buruk pada kesehatan anak. ${ }^{21}$ Penelitian lain di Bangladesh yang menunjukkan bahwa proporsi wasting pada anak balita menurun seiring dengan meningkatnya pendidikan kepala keluarga, yang menunjukkan proporsi balita wasting lebih banyak pada kelompok bapak yang pendidikan rendah. ${ }^{22}$ Di Indonesia, biasanya ibu yang mengambil peranan paling besar dalam mengasuh anak, sehingga tingkat pendidikan ibu yang lebih berpengaruh terhadap status gizi anak dibandingkan dengan tingkat pendidikan bapak. ${ }^{21}$ Begitu juga dengan pekerjaan orang tua, anak-anak yang sangat kurus dan kurus lebih banyak pada orang tua dengan pekerjaan yang bersifat unskill dibandingkan pada kelompok bapak dengan jenis pekerjaan skilled. Anak balita dari bapak dengan jenis pekerjaan skilled lebih rendah berisiko menderita moderate wasting.22 Jenis pekerjaan orang tua dengan pendapatan yang tetap setiap bulannya dan tidak tetap sangat terpengaruh oleh fluktuasi kondisi ekonomi negara. Pendapatan yang tetap setiap bulannya akan menjamin stabilnya ketahanan pangan keluarga dan pada akhirnya akan menjamin status gizi keluarga.

Hasil penelitian secara statistik menunjukkan terdapat hubungan signifikan antara tinggi badan kepala keluarga dan berat badan keluarga dengan status gizi balita (indeks $\mathrm{TB} / \mathrm{U}$ ), begitu juga dengan tinggi badan ibu, tetapi untuk berat badan ibu tidak menunjukkan hubungan bermakna di Kabupaten Aceh Besar. 
Stunting atau balita kependekan memberikan indikasi masalah gizi yang sifatnya kronis sebagai akibat dari keadaan yang berlangsung lama seperti kemiskinan, perilaku hidup tidak sehat, dan asupan makanan kurang dalam jangka waktu lama sejak usia bayi sehingga mengakibatkan anak menjadi pendek. Permasalahan malnutrisi tersebut berdampak terhadap masalah gizi kronis maupun gizi akut. ${ }^{4}$

Berkaitan dengan antropometri orang tua di Aceh Besar, searah dengan hasil penelitian di Bali, Jawa Barat dan NTT yang menyatakan tinggi badan orang tua dibawah standar menjadi faktor risiko balita kependekan pada usia 0-23 bulan sebesar 1,8 kali dibandingkan kondisi antropometri orang tua yang normal dengan nilai $p=0,000.23$ Hal yang sama juga ditemukan di Kecamatan Semarang Timur, ternyata juga menemukan bahwa disebabkan oleh ibu yang pendek sebesar 3,4 kali ( $p=$ $0,021)$ dan tinggi badan ayah yang pendek sebesar $3,2(p=0,034)$ dibandingkan pada kondisi normal. ${ }^{24}$ Kondisi antropometri orang tua seperti tinggi badan sangat berhubungan dengan pertumbuhan fisik balita. Secara signifikan sebenarnya ibu yang mempunyai tinggi badan pendek merupakan salah satu faktor penyebab terjadinya kependekan pada anak. ${ }^{8}$ Salah satu atau kedua orang tua yang pendek akibat kondisi patologi (seperti defisiensi hormon pertumbuhan) memiliki gen dalam kromosom yang membawa sifat pendek sehingga memperbesar peluang anak mewarisi gen tersebut dan tumbuh menjadi malnutrition. Akan tetapi, bila orang tua pendek akibat kekurangan zat gizi atau penyakit, kemungkinan anak dapat tumbuh dengan tinggi badan normal selama anak tersebut tidak terpapar faktor risiko yang lain. ${ }^{25}$ Selain itu bahwa anak yang dilahirkan dari ibu atau ayah pendek berisiko menjadi balita pendek. ${ }^{26}$ Postur tubuh orang tua juga mencerminkan tinggi badan ayah dan ibu serta kondisi lingkungan awal yang akan memberikan kontribusi terhadap tinggi badan anak sebagai faktor independen. Namun demikian, masih banyak faktor lingkungan yang mempengaruhi tinggi badan anak. ${ }^{27}$ Selan itu, beberapa penelitian lain menunjukkan bahwa terdapat faktor pendidikan dan pekerjaan yang berkaitan dengan karakteristik orang tua sebagai penyebab tingginya masalah balita pendek di Aceh Besar. Karakteristik pendidikan orang tua berdampak terhadap stunting balita, hasil penelitian di Semarang ${ }^{24}$ menunjukkan sebesar 4,3 kali rendahnya komposisi pendidikan ayah atau kepala keluarga berdampak terhadap stunting pada anak 24 36 bulan $(p=0,013)$, lebih lanjut hasil penelitian lain menunjukkan bahwa pendidikan kepala keluarga menengah ke bawah sebesar 1,2 kali akan menyebabkan anak stunting pada keluarga dengan ekonomi mampu $(p=0,013)$ di Indonesia. ${ }^{28}$ Sementara ibu-ibu yang berpendidikan rendah juga berhubungan dengan stunting pada anak $(p=0,000)$ dengan peluang sebesar 1,8 kalii23, kondisi ini berkaitan dengan praktek perawatan dan kondisi rumah tangga, khususnya pendidikan ibu tidak mempunyai kesetaraan dalam lingkungannya cenderung mempunyai anak pendek sebesar 2,8 kali dibandingkan ibu-ibu dengan pendidikan yang lebih baik. ${ }^{29}$

Menurut Mulvani, bahwa masyarakat dengan tingkat pendidikan yang tinggi, pada umumnya lebih memperhatikan masalah kesehatannya. ${ }^{30}$ Pada saat krisis prevalensi stunting cenderung meningkat pada anak dengan orang tua yang berpendidikan rendah, sehingga berpengaruh terhadap pengetahuan. Rendahnya pengetahuan makanan yang bergizi akan memberi dampak dalam mengakses informasi gizi dan aplikasinya dalam kehidupan keluarga. Selain itu juga mengakibatkan perubahan sikap dan perilaku hidup sehat menjadi kurang baik, sebaliknya tingkat pendidikan yang lebih tinggi memudahkan seseorang atau masyarakat untuk menyerap informasi dan mengimplementasikannya dalam perilaku dan gaya hidup sehari-hari, khususnya dalam hal kesehatan dan gizi. Oleh karena itu tidak bisa dipungkiri bahwa tingkat pendidikan wanita mempengaruhi derajat kesehatan. ${ }^{31-33}$

Hasil penelitian menunjukkan hubungan signifikan antara berat dan tinggi badan kepala keluarga dengan status gizi balita (indeks $\mathrm{BB} / \mathrm{U})$, sedangkan berat dan tinggi badan ibu tidak menunjukkan hubungannya di Kabupaten Aceh Besar. Prevalensi balita underweight (balita gizi buruk dan kurang) merupakan kejadian rendahnya berat badan berdasarkan umur pada balita sehingga menyebabkan gizi kurang dan gizi buruk, dan memberikan indikasi masalah gizi yang bersifat kronis sebagai akibat dari keadaan kemiskinan, perilaku hidup tidak sehat, dan asupan makanan kurang pada masa 
balita dan berakibat terhdap kehilangan berat badan normal. ${ }^{4}$

Hasil penelitian tersebut, sejalan dengan penelitian di Tangerang 26 bahwa besarnya prevalensi masalah gizi pada balita salah satu akibat dari faktor tinggi badan orang tua, yakni sebesar 2,2 kali akibat orang tua yang pendek. Selain itu, bahwa tinggi orang tua erat kaitannya dengan tinggi badan dan berat badan anak usia sekolah di Palangkaraya ${ }^{34}$. Teori yang mendukung hal tersebut, yaitu salah satu atau kedua orang tua yang pendek akibat kondisi patologi memiliki gen dalam kromosom yang membawa sifat pendek sehingga memperbesar peluang anak mewarisi gen tersebut dan tumbuh menjadi malnutrition. Akan tetapi, bila orang tua pendek akibat kekurangan zat gizi atau penyakit, kemungkinan anak dapat tumbuh dengan tinggi badan normal selama anak tersebut tidak terpapar faktor risiko yang lain. ${ }^{25}$ Penelitian di Libya, yang menyimpulkan bahwa keadaan antropometri orang tua seperti tinggi badan ayah dan ibu juga akan memberikan kontribusi terhadap tinggi badan pada anak. Namun demikian, tidak tertutup kemungkinan terdapat faktor lain yang dapat mempengaruhi tinggi badan anak yang tidak normal. ${ }^{15}$ Kelanjutan masalah kekurang berat badan bukan hanya disaat anak sampai 5 tahun, tetapi hasil penelitian menunjukkan sampai anak tersebut berusi 23 tahun menurut jenis kelaminnya, diantara anak laki-laki yang kekurangan berat badan sebesar 28,7 persen mengalami gizi buruk dan kurang pada usia 23 tahun, sementara 30,5 persen perempuan underweight menjadi wanita kurus. Memiliki orang tua pendek tidak menutup kemungkinan pada saat dewasa masih mengalami kekurangan berat badan, selain itu tertundanya pertumbuhan pada anak-anak dengan masa pubertas juga memungkinkan anak-anak mengalami gagal tumbuh atau failure to thrive..$^{35}$ Status balita dengan gizi buruk dan kurang juga kemungkinan disebabkan faktor pendidikan orang tua. Penelitian Ulfani, dkk., ${ }^{36}$ yang menyatakan bahwa tingkat pendidikan orang tua mempunyai korelasi positif dengan kejadian underweight pada balita, yakni sebesar 38,9 persen $(p=0,000)$. Selain itu menurut Chandra, ${ }^{37}$ bahwa masalah gizi selain disebabkan masalah sosial ekonomi juga faktor rendahnya pendidikan ibu berhubungan dengan status gizi, ibu yang pendidikan rendah cenderung menghabiskan pekerjaannya dirumah $(66,2 \%)$ dan mempunyai anak dengan gizi normal dibandingkan yang bekerja di luar rumah. Rendahnya pendidikan formal orang tua mempunyai peluang terhadap kejadian malnutrition, besarnya peluang tersebut, yaitu pendidikan kepala keluarga 2,9 persen di daerah pedesaan 5,4 persen di perkotaan, serta pada pendidikan ibu di pedesaan 4,4 persen dan di perkotaan 5,0 persen..$^{38}$ Pendidikan yang tinggi belum tentu menjamin ibu untuk berperilaku baik terkait kesehatan dan status gizi balita, apalagi kondisi dengan ibu-ibu yang berpendidikan rendah. Ibu yang berpendidikan tinggi maupun rendah, saling mempunyai kesempatan dalam mendapatkan informasi dan pengetahuan yang baik untuk menunjang perilaku kesehatan dan status gizi balita. Kemajuan teknologi dan informasi saat ini memungkinkan ibu-ibu dalam mengakses informasi seputar kesehatan gizi melalui berbagai media seperti media sosial, internet, media masa bahkan secara konvensional seperti posyandu, kader, bidan, lingkungan setempat seperti keluarga dan tetangga. ${ }^{39}$ Oleh karena itu, pendidikan formal orang tua bukan lagi sebagai faktor penentu terhadap ibu atau kepala keluarga dalam meningkatkan pengetahuannya.Selain itu rendahnya pengetahuan ibu tentang gizi, kepercayaan ibu yang kurang baik terhadap makanan tertentu, tidak tersedianya fasilitas kesehatan, tidak adanya kebijaksanaan pemerintah terhadap penanggulangan masalah gizi dan penghasilan keluarga yang rendah berdampak terhadap tinggi angka kekurangan gizi pada balita. ${ }^{40}$

\section{SIMPULAN DAN SARAN}

\section{Simpulan}

Tingginya masalah gizi kronis dan akut di Kabupaten Aceh Besar merupakan akibat faktor antropometri orang tua yang berperan dalam besarnya prevalensi gizi terutama berat dan tinggi badan kepala keluarga. Secara proporsional berat dan tinggi badan orang tua berhubungan dengan status gizi balita berdasarkan indikator BB/TB maupun indikator $T B / U$, kecuali berat badan ibu yang tidak menunjukkan hubungan bermakna. Selanjutnya 
menurut indeks BB/U (gizi akut), menunjukkan berat dan tinggi badan kepala keluarga berhubungan dengan status gizi balita, tetapi berat dan tinggi badan ibu tidak menunjukkan hubungannya terhadap status gizi balita di Kabupaten Aceh Besar. ketidakseimbangan karakteristik pendidikan dan pekerjaan orang tua, memungkinkan balita mengalami masalah gizi terutama gizi kronis dan gizi akut.

\section{Saran}

Diharapkan perbaikan masalah gizi melalui
pendekatan secara langsung seperti pemantauan pertumbuhan secara kontinu, penyuluhan tentang ASI eksklusif dan vitamin A serta MP-ASI. Selain itu pemberian makanan tambahan pada ibu dan tablet tambah darah. Selain itu, upaya terhadap perilaku hidup bersih dan sehat (PHBS) harus terpenuhi oleh setiap rumah tangga di Aceh Besar. Orang tua yang mempunyai tinggi badan di bawah normal berdampak terhadap tinggi badan anak, dalam memilih pasangan hidup baik calon suami maupun calon istri sebaiknya dilakukan seleksi atau dipilih yang mempunyai tinggi badan normal.

\section{UCAPAN TERIMA KASIH}

Ucapan terima kasih disampaikan kepada Direktur Poltekkes Kemenkes Aceh, selaku penyedia anggaran dan memonitoring pelaksanaan penelitian ini. Terima kasih kami ucapkan kepada Kepala Dinas Kesehatan Aceh Besar dan Kepala Puskesmas dalam wilayah Kabupaten Aceh Besar, yang turut membantu memperlancar jalannya penelitian ini. Serta responden dan enumerator menyediakan waktu luangnya demi jalannya penlitian ini. Semoga bantuan yang diberikan mendapat imbalan dari Allah SWT, dan hasil yang diperoleh dalam penelitian ini bermanfaat dalam pengembangan ilmu kesehatan, khususnya bidang gizi.

\section{RUJUKAN}

1. Van de Pas R, Hill PS, Hammonds R, Ooms G, Forman L, Waris A, et al. Global health governance in the sustainable development goals: Is it grounded in the right to health? Global Challenges 2017: 47-60.

2. Kementerian Perencanaan Pembangunan Nasional/Badan Perencanaan

Pembangunan Nasional. Rencana Pembangunan Jangka Menengah Nasional 2015-2019. Buku I: Agenda Pembangunan Nasional Jakarta: Kementerian Perencanaan Pembangunan Nasional/Badan Perencanaan Pembangunan Nasional, 2014.

3. Tambipi S. Enam Provinsi Sulit Keluar dari Permasalahan Kemiskinan dan Prevalensi Gizi Kurang. 28 Feb 2015: [2-3 pp]. Available from: http://gizi.depkes.go.id/download_gizinet.

4. Badan Penelitian dan Pengembangan Kesehatan (Balitbangkes). Pokok-pokok Hasil Riskesdas Nangroe Aceh Darussalam Tahun 2013. Jakarta: Balitbangkes Kementerian Kesehatan RI, 2013.

5. Syafrida $E$, Lindawati, Alfridsyah, ALRahmad AH, Yusniwati. Laporan Manajemen Data Survei Pemantauan Status Gizi Provinsi Aceh Tahun 2015. Banda Aceh: Dinas Kesehatan Aceh dan Jurusan Gizi Poltekkes Kemenkes RI Aceh. 2015.

6. Amosu AM, Degun AM, Atulomah NOS, Olanrewju MF. A study of the nutritional status of under- 5 children of low-income earners in a South-Western Nigerian Community. Current Research Journal of Biological Sciences. 2011; 3(6):578-85.

7. Yang X, Ye R, Zheng J, Ren A. Analysis on influencing factors for stunting and underweight among children aged 3-6 years in 15 counties of Jiangsu and Zhejiang provinces. Chinese Journal of Epidemiology. 2010; 31(5): 509-9.

8. Zottarelli LK, Sunil TS, Rajaram S. Influence of parental and socioeconomic factors on stunting in children under 5 
years in Egypt. East Mediterr Health $\mathrm{J}$. 2007; 13(6): 1330-42.

9. Hanum $F$, Khomsan $A$, Heryatno $Y$. Hubungan asupan gizi dan tinggi badan ibu dengan status gizi anak balita. Jurnal Gizi dan Pangan. 2014; 9(1): 1-6.

10. Purnamasari $H$, Gunarso U, Rujito L. Overweight sebagai faktor risiko low back pain pada pasien poli saraf RSUD Prof. Dr. Margono Soekarjo, Purwokerto. Mandala of Health. 2010; 4(1): 26-32.

11. Sudikno, Syarief $H$, Dwiriani $C M$, Riyadi $H$. Faktor risiko overweight dan obese pada orang dewasa di Indonesia: Analisis data Riset Kesehatan Dasar 2013. Gizi Indon. 2015; 38(2): 91-104.

12. Sartika RAD. Faktor risiko obesitas pada anak 5-15 tahun di Indonesia. Makara Kesehatan. 2011; 15(1): 37-43.

13. Lee K, Kwon E-R, Park T-J, Park M-S, Lenders CM. Parental overweight as an indicator of childhood overweight: how sensitive? Asia Pac J Clin Nutr. 2006; 15(2): 196-200.

14. Zetlin M. Balita di Negara-Negara Berkembang, Peran Pola Asuh Anak, Pemanfaatan Hasil Studi Penyimpangan Positif Untuk Program Gizi. Prosiding Widyakarya Nasional Pangan dan Gizi VII; Jakarta. Jakarta: Kerjasama LIPI, Bappenas, UNICEF, Deptan, Depkes, BPS; 2000. p. 125-55.

15. Ruel MT, Alderman $\mathrm{H}$, and the Maternal and Child Nutrition Study Group. Nutritionsensitive interventions and programmes: how can they help to accelerate progress in improving maternal and child nutrition? Lancet. 2013; 382(9891): 536-51.

16. Dahlan MS. Statistik untuk Kedokteran dan Kesehatan. Edisi ke-5. Jakarta: Penerbit Salemba Medika, 2011.

17. Rahmawati P. Management of diabetes mellitus type II not controlled with hypertension grade I. J Medula Unila. 2014; 3(1): 80-90.
18. Dinkes. Profil Kesehatan Kabupaten Aceh Besar Tahun 2015. Aceh Besar: Dinas Kesehatan Kabupaten Aceh Besar; 2015.

19. World Health Organization (WHO). Nutrition Landscape Information System (NLIS) Country Profile Indicators: Interpretation Guide. Geneva: WHO, 2010.

20. Barker M. Nutrition in the Womb. USA: The Barker Foundation, 2008.

21. Putri DSK, Wahyono TYM. Faktor langsung dan tidak langsung yang berhubungan dengan kejadian wasting pada anak umur 6-59 bulan di Indonesia tahun 2010. Media Litbangkes. 2013; 23(3): 110-21.

22. Rayhan MI, Khan MSH. Factors causing malnutrition among under five children in Bangladesh. Pak J Nutr. 2006; 5(6): 55862.

23. Nadiyah, Briawan D, Martianto D.- Faktor risiko stunting pada anak usia 0-23 bulan di Provinsi Bali, Jawa Barat, dan Nusa Tenggara Timur. Jurnal Gizi dan Pangan. 2014; 9(2): 125-32.

24. Nasikhah $\mathrm{R}$ Margawati $\mathrm{A}$. Faktor risiko kejadian stunting pada balita usia 24-36 bulan di Kecamatan Semarang Timur. Semarang: Program Studi IImu Gizi Fakultas Kedokteran Universitas Diponegoro, 2012.

25. Amigo $H$, Bustos $P$, Radrigán $M E$. Is there a relationship between parent's short height and their children's? Social interclass epidemiologic study. Rev Med Chil. 1997; 125(8); 863-8.

26. Rahayu LS. Associated of height of parents with changes of stunting status from 6-12 months to 3-4 years. Thesis. Yogyakarta: Department of Health Science, Faculty of Medicine, Universitas Gajah Mada, 2011.

27. El Taguri A, Betilmal I, Mahmud SM, Monem Ahmed A, Goulet O, Galan P, et al. Risk factors for stunting among under- 
fives in Libya. Public Health Nutr. 2009; 12(8): 1141-9.

28. Aries $M$, Hardinsyah, Tuhiman $H$. Determinan gizi kurang dan stunting anak umur 0-36 bulan berdasarkan data program Keluarga Harapan (PKH) 2007. Jurnal Gizi dan Pangan. 2012; 7(1): 19-26.

29. Garcia S, Sarmiento OL, Forde I, Velasco $T$. Socio-economic inequalities in malnutrition among children and adolescents in Colombia: the role of individual-, household- and communitylevel characteristics. Public Health Nutr. 2013; 16(9): 1703-18.

30. Mulvany C. Deficits, DSH, and consumer behavior observations from the January CBO report. Healthcare Financial Management: Journal Of The Healthcare Financial Management Association. 2015; 69(4): 34-6.

31. Tarigan IU. Faktor-faktor yang berhubungan dengan status gizi anak umur 6-36 bulan sebelum dan saat krisis ekonomi di Jawa Tengah. Bul Penel Kesehatan. 2003; 31(1): 1-12.

32. Hardinsyah. Review faktor determinan keragaman konsumsi pangan. Jurnal Gizi dan Pangan. 2007; 2(2): 55-74.

33. Depkes RI. Analisis Situasi Gizi \& Kesehatan Masyarakat. Jakarta: Direktorat Jenderal Bina Kesehatan Masyarakat. Direktorat Gizi Masyarakat. Departemen Kesehatan Rl; 2004.

34. Norliani, Sudargo T, Budiningsari RD. Tingkat sosial ekonomi, tinggi badan orang tua dan panjang badan lahir dengan tinggi badan anak baru masuk sekolah. Berita Kedokteran Masyarakat (BKM). 2003; 21(4).

35. Greco L, Power C, Peckham C. Adult outcome of normal children who are short or underweight at age 7 years. BMJ Clin Res. 1995; 310(6981): 696-700.

36. Ulfani DH, Martianto D, Baliwati YF.Faktor-faktor sosial ekonomi dan kesehatan masyarakat kaitannya dengan masalah gizi underweight, stunted, dan wasted di Indonesia: Pendekatan ekologi gizi. Jurnal Gizi dan Pangan. 2011; 6(1): 59-65.

37. Chandran V. Nutritional Status of Preschool Children: a Socio-economic Study of Rural Areas of Kasaragod District in Kerala. Journal of Shodhganga. 2009; X(December 2009): 163

38. Semba RD, de Pee S, Sun K, Sari M, Akhter N, Bloem MW. Effect of parental formal education on risk of child stunting in Indonesia and Bangladesh: a crosssectional study. Lancet. 2008; 371(9609): 322-8.

39. Pratiwi RH, Suyatno S, Aruben R. Faktorfaktor yang berhubungan dengan beratkurang (underweight) pada balita di perkotaan dan perdesaan Indonesia berdasarkan data Riskesdas tahun 2013. Jurnal Kesehatan Masyarakat (e-Journal). 2015; 3(2): 127-37.

40. Fatimah S, Nurhidayah I, Rakhmawati W. Faktor-faktor yang berkontribusi terhadap status gizi pada balita di Kecamatan Ciawi Kabupaten Tasikmalaya. Majalah Keperawatan Unpad. 2008;10(18):37-51. 
